\title{
Fish species richness in lakes of the northeastern lowlands in Germany
}

Eckmann R. Fish species richness in lakes of the northeastern lowlands in Germany:

Ecology of Freshwater Fish 1995: 4: 62 69. (C) Munksgaard. 1995

Abstract Fish species richness was assessed by electrofishing and gillnelting in 16 lakes of the northeastern lowland in Germany (the Schorfheide hiosphere reserve). The lakes range from 0.03 to $10.55 \mathrm{~km}^{2}$ and support hetween 5 and 14 fish species. Species richness is significantly correlated with lake area in an exponential and a power model. Richness is also correlated with shoreline development and total dissolved solids. This unports the hypothesis that larger areas contain more species within a " nnomic group due to increased habitat diversity. The slope of the spe(is. 1) curve is low compared with most other studies of fish species richness in lakes, and the intercept value is high. This is interpreted as the result of high habitat and food diversity. lack of stress from abiotic factors, and the small regional species pool from which these lakes can be colonized. Two species inventories, one from the beginning of this century and one from the 1950s, are available for comparison. Average species richness did not change during the last decades. Species turnover rates were not related to the degree of anthropogenic eutrophication or to the intensity of fishery exploitation in these lakes. On the species level, however, one effect of accelerated eutrophication is apparent. the disappearance of 4 botlom-living species from one to 6 of the study lakes.

\section{R. Eckmann}

Institute of Freshwater and Fisn Ecology Department of Biology and Ecology of Fish Berlin. Germany

Key words: species richness; lake; fish

Reiner Eckmann. Institute of Freshwater and Fish Ecology, Department of Blology and Ecology of Fish, Mueggeiseedamm 310. D-12587 Berlın. Germany

Accepted for publication January 10. 1995

\section{Introduction}

There are 3 major hypotheses as to why more specles within a taxonomic group exist in larger areas (Angermeier \& Schlosser 1989). The first, the areaper se hypothesis, is derived from island biogeography (Mac Arthur \& Wilson 1967) and considers species richness as the result of an equilibrium between immigration and extinction rates, which are botl) dependent on habitat size (Magnuson 1976). 7 he second, the habitat diversity hypothesis (William 1964 ), suggest that larger habitats contain $1 \cdots 1$ uhdivisions of habitat configurations and resources and thus. maintain more species. The land the sampling hypothesis (Connor \& McCoy $1+9 \%$, views species number as the result of passive smpling lrom the available species pool, whereby l: mately. more species.

Species-area curves were first documented for terrestrial organisms on islands. Subsequently, the similarities between ocean islands and lakes have been pointed out (Barbour \& Brown 1974: Magnuson 1976) and species-area curves documented for a variety of aquatic taxa including littoral zooplankton (Fryer 1985). pelagic zooplankton (Dodson 1991), snails (Brönmark 1985), and fish (Barbour \& Brown 1974; Browne 1981; Eadie \& Keast 1984: Eadie et al. 1986: Harvey 1978, 1981: Matuszek \& Beggs 1988: Matuszek. Goodier \& Wales 1990: Rahel 1986; Somers \& Harvey 1984: Tonn \& Magnuson 1982). These studies show that in lacustrine fish communities, parameters other than lake area may also be significantly correlated with species richness. These include latitude. altitude. lake depth. shoreline development, $\mathrm{pH}$. winter oxygen concentrations and lake connectedness, substrate diversity, submerged macrophyte complexily. and invertebrate prey diversity.

The purpose of this article is to investigate relationships between fish species richness and morphometry (area. depth, shoreline development) and indices of trophic state (conductivity/total dissolver solids, total P. chlorophyl a) for a set of 16 lakes of 
glacial origin in the northeastern lowland in Germany. Additionally, since many of these lakes have suffered from severe anthropogenic impact during the last decades (eutrophication, intensive fish production. stocking with exotics), it should be tested whether species richness or species composition were persistently affected by these perturbations.

\section{Material and methods}

Sixteen lakes in the Schorfheide biosphere reserve, situated about $100 \mathrm{~km}$ north of Berlin, were used in these analyses. They were primarily selected to include the range of lake sizes available in this region. and secondarily to represent wide arrays of trophic state and human impact. Surface area and shoreline length were measured from digitized areal photographs or ordnance maps. Maximum and mean depth were taken from files of a statewide assessment of the fish production potential in lakes of the German Democratic Republic carried out in the 1950s. Vertical temperature and oxygen profiles (Syland model 4002 F) and Secchi depth nere measured parallel to each fishing operation. Conductivity and total dissolved solids (TDS) were determined on two occasions in 14 lakes. From the linear relationsthip TDS $[\mathrm{mg} / \mathrm{l}]=28+0.68$ conductivity $[\mu \mathrm{S} / \mathrm{cm}]\left(n=27 . R^{2}=0.96\right)$. TDS was estimated for the two lakes for which only conductix ity measurements were available. Total phosphorus and chlorophyll-a concentrations were measured 3 times during the growing season in representative samples from the epilimnetic water column. The extent of the reed belt. abundance of submersed macrophytes and presence of connections with other waterbodies were assessed by visual inspection. Winterkills were reported by fishermen and residents and by personal observations. These sources were also used to assess type and severity of human impact during the last decades.

Fish sampling was carried out in 2 conseeutive years. In 1992. each lake was fished once in summer with 4 bottom-set gill nets of 12.18, 26 and $32 \mathrm{~mm}$ bar mesh. 1.2 to $2.4 \mathrm{~m}$ height and 10 to 25 $\mathrm{m}$ length. Additionally. several littoral sites per lake were sampled by electrofishing and with a 30 $\mathrm{m}$ beach seine of $6-\mathrm{mm}$ mesh size. During the growing season 1993, the 12 smaller lakes were fished once and the four larger ones twice with a new fleet of eight gill nets of $12.16,20,25,32,40$, 50 and $60 \mathrm{~mm}$ bar mesh. 1.2 to $2.4 \mathrm{~m}$ height and 10 to $25 \mathrm{~m}$ length. Electrofishing was done as in the previous year, but the beach seine was not used. Fish caught in gill nets were easily identified, except small individuals of bream and white bream whose identity was verified by scale and fin ray counts. Whenever the identity of small fish sampled by electrofishing was doubiful, samples were preserved for later identification in the laboratory. Only the species that were present in our samples were included in the species list, except for coregonids, whose presence was confirmed by professional catches. Accidentally or intentionally introduced exotics (Oncorhynchus mykiss, Cyprimus ('arpio and Aristichtys nobilis), which do not reproduce in the recipient lake. were not counted. Scientific and common names of fish species are given in the Appendix. Historical species lists for 14 of the 16 study lakes were available for the beginning of this century (Eckstein 1908) and for the 1950s (files from the former Inland Fisheries Institute of the German Democratic Republic).

\section{Results}

The lakes range in surface area from 0.03 to 10.55 $\mathrm{km}^{2}$ and from 2 to $50 \mathrm{~m}$ maximum depth (Table 1). In 12 permanently stratified lakes. however, oxygen depletion in the hypolimnion $\left(\leq 1 \mathrm{mg} \mathrm{O}_{2} / 1\right)$ restricts fish distribution to only two thirds of maximum depth on average during the growing season. Winterkills have only been reported for the two smallest lakes. Most lakes are either completely isolated from other water bodies or are only temporarily connected to small ditches. and only 3 lakes have a permanent outlet creek or ship canal that permits fish movements. The lakes' trophic states range from mesotrophic $(<10 \not$ thg chl-a/l) to heavily polluted (around $100 \mathrm{pg}$ chl-a/l). Reed stands (mainly Phragmites and Tipha) are usually present. and in some lakes they occupy a large portion of the littoral zone. Submerged vegetation (Potomlogeton, Miriophy/lam, Ceratophy/lum, Chara and also Stratiotes) is present in almost all lakes, but in the most turbid lakes it is not abundant or even rare. During the last decades. 10 lakes were managed by fisheries cooperatives, including 3 lakes with intensive net-cage culture using pelleted food. whereas 6 lakes were only fished by hook and line (Table 1).

A total of 19 fish species were found. which could be classified as either being ubiquitous (present in 11 to 16 lakes) or nonubiquitous species (present in only 1 to 6 lakes) (Table 2). Species numbers per lake range from 5 to 14 . If the species number that was documented after two years of fishing is set to 100 , then an average of $86 \%$ of all species records had already been obtained after the first study year. The highest numbers of new species per lake that were observed in the second study year belong to the largest lakes. exeept for Kleinvätersee. which was sampled inappropriately in the first year, and Tiefer See. which was sampled in the second year only. If the number of species 
Table 1. Basıc morphometric and IImnological data for the 16 study lakes.

\begin{tabular}{|c|c|c|c|c|c|c|c|c|c|c|c|c|c|c|c|c|}
\hline & $\begin{array}{l}\text { Kleiner } \\
\text { Döllnsee }\end{array}$ & $\begin{array}{l}\text { Teutzen- } \\
\text { see }\end{array}$ & $\begin{array}{l}\text { Kleinvàter- } \\
\text { see }\end{array}$ & $\begin{array}{c}\text { Großvàter- } \\
\text { see }\end{array}$ & $\begin{array}{c}\text { Großer } \\
\text { Krinertsee }\end{array}$ & $\begin{array}{l}\text { Duester- } \\
\text { see }\end{array}$ & $\begin{array}{l}\text { Klarer } \\
\text { See }\end{array}$ & $\begin{array}{l}\text { Luebbe- } \\
\text { see }\end{array}$ & $\begin{array}{l}\text { Werbellin- } \\
\text { see }\end{array}$ & $\begin{array}{l}\text { Wolletz- } \\
\text { see }\end{array}$ & $\begin{array}{l}\text { Grimnitz- } \\
\text { see }\end{array}$ & $\begin{array}{l}\text { Rederns- } \\
\text { walder See }\end{array}$ & $\begin{array}{l}\text { Parsteiner } \\
\text { See }\end{array}$ & $\begin{array}{l}\text { Kleiner } \\
\text { Flunzsee }\end{array}$ & $\begin{array}{c}\text { Großer } \\
\text { Plunzsee }\end{array}$ & $\begin{array}{l}\text { Tiefer } \\
\text { See }\end{array}$ \\
\hline area $\left(\mathrm{km}^{2}\right)$ & 0.24 & 0.03 & 0.09 & 0.12 & 0.75 & 0.42 & 0.47 & 3.14 & 8.04 & 3.29 & 7.93 & 0.53 & 10.5 & 0.04 & 0.22 & 0.10 \\
\hline shoreline (km) & 2.3 & 0.8 & 1.4 & 15 & 7.1 & 4.5 & 4.2 & 22.1 & 27.2 & 16.0 & 13.1 & 6.0 & 32.0 & 0.9 & 2.2 & 1.5 \\
\hline SLDF & 1.3 & 1.3 & 1.3 & 1.2 & 2.3 & 2.0 & 1.7 & 3.5 & 2.7 & 2.5 & 1.3 & 2.3 & 2.8 & 1.3 & 1.3 & 1.3 \\
\hline max. depth (m) & 8 & 2 & 14 & 13 & 10 & 8 & 7 & 12 & 50 & 18 & 11 & 12 & 27 & 4 & 10 & 33 \\
\hline TDS (mg/l) & 236 & 196 & 194 & 200 & 438 & 405 & 310 & 309 & 250 & 416 & 372 & 199 & 347 & 473 & 290 & 233 \\
\hline total-P $(\mu \mathrm{g} / \mathrm{l})$ & 21 & 80 & 17 & 23 & 27 & 48 & 98 & 37 & 40 & 150 & 65 & 36 & n.d. & 1270 & 148 & n.d. \\
\hline chlorophyll-a $(\mathrm{g} / \mathrm{l})$ & 9.8 & 6.8 & 2.8 & 4.2 & 7.6 & 21.9 & 42.6 & 9.1 & 4.7 & 11.8 & 10.2 & 8.8 & n.d. & 100 & 15.0 & n.d. \\
\hline in/outflow & $(+)$ & & & & $11)$ & $(+1)$ & - & + & 1 & + & $(+)$ & & $(+)$ & (1) & $(+)$ & \\
\hline hypolimnetic anoxia & 1 & - & 1 & 1 & + & + & 1 & , & - & + & & + & & + & 1 & - \\
\hline winterkill & - & t & & & - & - & & - & - & & - & - & & + & & - \\
\hline reed belt & + & 1 & 1 & + & ++ & t & & + & + & 1 & ++ & 1 & ++ & & t & + \\
\hline submerged vegetation & +1 & & + & - & 11 & + & & +1 & 1 & + & t & t+ & + & & - & 1 \\
\hline human impact & $\mathrm{hl}$ & $\mathrm{hl}$ & $\mathrm{hl}$ & eu & $\mathrm{hl}$ & eu & eu & ts & ts & $\mathrm{cc}$ & $\mathrm{bc}, \mathrm{cc}$ & ts & $\mathrm{CC}$ & eu & $\mathrm{bc}$ & $\mathrm{hl}$ \\
\hline & & & & hl & ts & ts & ts & & & eu,ts & eu.ts & & eu,ts & hl & eu,ts & \\
\hline
\end{tabular}

SLDF: shoreline development factor. TDS (total dissolved solids). total-P and chlorophyll-a are means from 2-3 eplimnetıc measurements during summer stagnation. in/oufflow: - absent: ( + ) present but generally not passable to fish; - regularly passable to fish. hypolimnetic anoxia: assessed during summer stagnation. reed belt: absent or only small isolated stands: i present, of moderate width: + + broad beit occupying large parts of shallow bays. submerged vegetation: - almost absent; 1 regularly present; + + abundant. human impact: bc - stocked with bighead carp: cc - cage culture. use of pelleted feedstuff; eu - eutrophication due to sewage input and/or runoff from agricultural soils: hl - fished with hook and line: ts - fished commercially with trap and seine nets

Table 2. Occurrence of 19 fish species in 16 lakes of northeastern Germany according to electric and gillnet fishıng (total number). The number of species that were tound in each study year are indicated as well as the number of species that were only discovered during the second year (new in 93)

\begin{tabular}{|c|c|c|c|c|c|c|c|c|c|c|c|c|c|c|c|c|c|}
\hline & $\begin{array}{l}\text { Kleiner } \\
\text { Döllnsee }\end{array}$ & $\begin{array}{l}\text { Teutzen- } \\
\text { see }\end{array}$ & $\begin{array}{l}\text { Kleinvater- } \\
\text { see }\end{array}$ & $\begin{array}{l}\text { Großvater- } \\
\text { see }\end{array}$ & $\begin{array}{c}\text { Großer } \\
\text { Krnertsee }\end{array}$ & $\begin{array}{l}\text { Duester- } \\
\text { see }\end{array}$ & $\begin{array}{l}\text { Klarer } \\
\text { See }\end{array}$ & $\begin{array}{l}\text { Luebbe- } \\
\text { see }\end{array}$ & $\begin{array}{l}\text { Werbellin- } \\
\text { see }\end{array}$ & $\begin{array}{l}\text { Wolletz- } \\
\text { see }\end{array}$ & $\begin{array}{l}\text { Grimnitz- } \\
\text { see }\end{array}$ & $\begin{array}{l}\text { Rederns- } \\
\text { walder See }\end{array}$ & $\begin{array}{l}\text { Parsteiner } \\
\text { See }\end{array}$ & $\begin{array}{l}\text { Kleiner } \\
\text { Plunzsee }\end{array}$ & $\begin{array}{c}\text { Großer } \\
\text { Plunzsee }\end{array}$ & $\begin{array}{l}\text { Tiefer } \\
\text { See }\end{array}$ & 2 \\
\hline $\begin{array}{l}\text { Anguilla ang. } \\
\text { C. albula/lavaret. }\end{array}$ & - & & & - & - & - & - & : & : & : & $\bullet$ & - & : & & & . & 11 \\
\hline Esox lucius & - & - & - & - & - & - & - & - & - & - & - & - & - & & - & - & 15 \\
\hline Abramis brama & - & & - & - & - & - & - & - & - & - & - & - & - & & - & - & 14 \\
\hline Alburnus albur. & - & & & - & - & - & - & - & - & - & - & - & - & & - & - & 13 \\
\hline Blicca bloerkna & - & & & - & - & - & - & - & - & - & - & - & - & & & & 11 \\
\hline Carassius car. & & - & - & - & & & & & & & - & & & & & & 4 \\
\hline Gobio gobio & & & & & & & & - & & - & & & - & & & & 3 \\
\hline Leucaspius del. & & - & & & & & & - & - & & - & & & - & & & 5 \\
\hline Rhodeus s. am. & & & & & - & & & & & & & & & & & & 1 \\
\hline Rutilus rutilus & - & - & - & - & - & - & - & - & - & - & - & - & - & - & - & - & 16 \\
\hline Scardinius ery. & - & & - & - & - & - & - & - & & - & - & - & - & - & - & - & 14 \\
\hline Tinca tinca & - & - & - & - & - & - & & - & - & & • & - & • & - & - & & 13 \\
\hline Gasterosteus a. & & & & & & & & & - & & - & & & & & & 2 \\
\hline Perca fluviatilis & - & - & - & - & - & - & - & - & - & - & - & - & - & - & - & - & 16 \\
\hline Gymnoceph.c. & - & & - & & - & - & - & - & - & - & - & & - & & - & & 11 \\
\hline Stizostedion $\mathrm{lu}$. & & & & & $\bullet$ & & - & & & : & - & & $\bullet$ & & $\bullet$ & & 6 \\
\hline Lota lota & & & & & & & & & - & - & & & & & & & 2 \\
\hline total number & 10 & 6 & 8 & 10 & 12 & 10 & 10 & 13 & 13 & 13 & 14 & 9 & 13 & 5 & 9 & 7 & \\
\hline No. of species in 1992 & 9 & 5 & 4 & 10 & 9 & 10 & 10 & 11 & 11 & 9 & 13 & 8 & 10 & 5 & 9 & - & \\
\hline No. of species in 1993 & 7 & 6 & 8 & 8 & 12 & 9 & 7 & 12 & 11 & 12 & 10 & 9 & 13 & 3 & 7 & 7 & \\
\hline new in 93 & 1 & 1 & 4 & 0 & 3 & 0 & 0 & 2 & 2 & 4 & 1 & 1 & 3 & 0 & 0 & 7 & \\
\hline
\end{tabular}


per lake is estimated as a function of fishing effort (number of study years) according to $S=a-1$ /fishing effort. one would expect an average asymptotic richness of 11.7 species per lake. excluding Tiefer See. instead of 10.3 species that have been found after two years of fishing.

The presence of 5 species (Anguilla anguilla, Tinca tinca, Gobio gobio, Rhodeus sericeus amarus and Perca fluviatilis) was documented by electrofishing and the presence of 5 species by gill-netting alone (Coregoms spp., Abramis brama. P. fluviatilis, Stizostedion lucioperca and Gymnoceplatus cermual). but the combination of both methods was necessary to obtain the complete species inventory for each lake. Beach seining was not necessary to complement the record obtained by the other two fishing methods. Correlation analyses showed significant relationships between species richness and surface area (Fig. 1), species richness and shoreline devclopment factor (the quotient of actual lake circumference and the perimeter of a circle of equal area) $(P<0.01)$ and species richness and TDS $(P<0.01)$. The last relationship is only significant if the second smallest lake (Kleiner Plunzsee) is deleted from the data set.

This lake has received sewage from a large animal farm for at least the past 20 years. and its TDS contcnt of more than $470 \mathrm{mg} / \mathrm{lin}$ relation 10 its species number (5) must be considered as an outlicr.

Regression analysis showed that shoreline development is no longer significantly correlated with species richness in a linear model where lake area is the other predictor variable. Similarly. TDS is not significant together with lake area as predictor

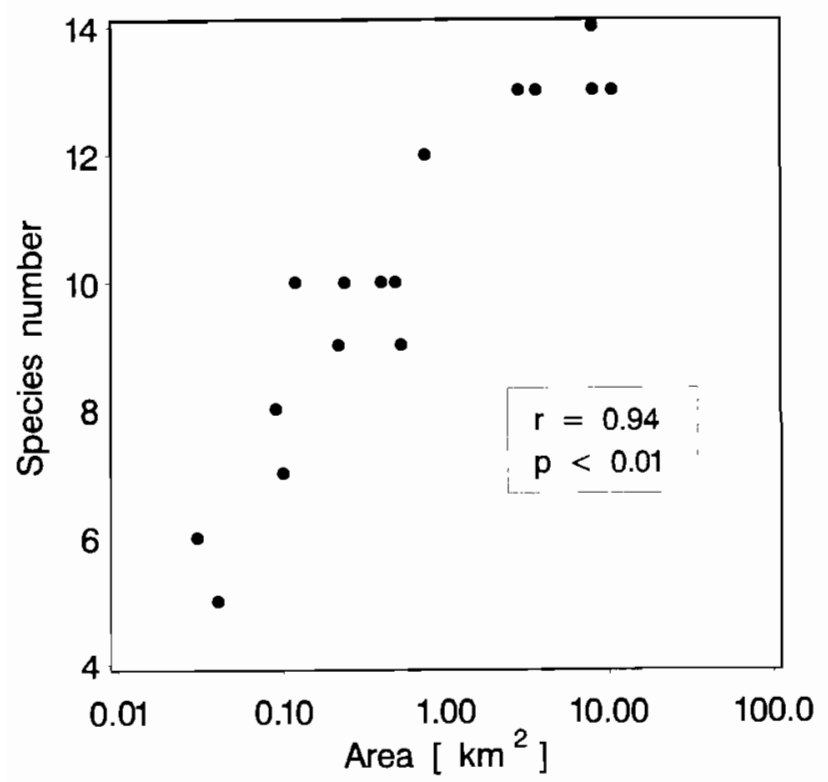

Fig. 1. Fish species richness in relation to lake surface area in 16 glacial lakes of the northeastern lowland in Germany variable for species richness. There was no correlation between species richness and either lake depth. total phosphorous content (excluding Kleiner Plunzsee) or chlorophyll a content. Species-area curves were fitted using an exponential model and a power function. The equations are:

$$
\text { and } \begin{array}{ll}
\mathrm{S}=10.99+3.07 \log _{110} \mathrm{~A} & \left(R^{2}=0.874\right) \\
\mathrm{S}=10.67 \times \mathrm{A}^{0.141} & \left(R^{2}=0.808\right)
\end{array}
$$

where $\mathrm{S}$ is species richness and $\mathrm{A}$ is lake area in $\mathrm{km}^{2}$.

\section{Discussion}

Species richness is significantly correlated with lake area in the present data sct (Fig. 1). The slope of the $\log$ species/log area regression line $(0.14)$. however, is low compared with most other studies on fish species richness in lakes (Table 3 ). If species richness is the result of an cquilibrium between colonization and extinction. then the slope value should fall in the range 0.20 .4 (Preston 1960). Higher slope values can be attributed to increased habitat diversity with area, and lower values may be the result of sampling nonisolated areas (Connor \& McCoy 1979). In the latter situation. many transient species will be encountered. independent of habitat size, thereby increasing species richness in small areas and depressing the slope of the species-area curve. It is unlikely that the presence of transient species is the reason for the low slope value in the present data set. These lakes. which were formed some 10.000 years ago. were highly connected initially by runoff from the retreating ice shield, allowing colonization from the available fish species pool. The lakes then became increasingly isolated. and contemporary colonization rates are probably very low and transient species insignificant.

An alternative explanation for low slope value is the asymptotic nature of species numbers for large areas (Connor \& McCoy 1979). This fundamental characteristic of species-area curves is masked when power functions are fitted to the data but is evident when exponential models (species/log area curves) are used. In the present case. the exponential model gives a better fit to the data $\left(R^{2}=0.87\right)$ than the power function $\left(R^{2}=0.81\right.$ ), and the asymptotic nature of the species-area relation is obvious: for every 10 -fold increase in area, richness is expected to rise by rougly 3 species, i.e.. even for a $1000 \mathrm{~km}^{2}$ lake we would expect only 20 fish species.

Species richness levels off at relatively low values, probably because the regional fish species pool is small. Of the 83 freshwater fish species that have been reported for Germany (Ladiges \& Vogt 1979). 6 are exotics. 9 live in brackish waters. 16 
Table 3. Regression equations used to predict fish species richness (S) from lake area (A), and predıcted richness for lakes of 0.1 . 1, and 10 km ${ }^{2}$ surface area. Orıginal equations were modified if necessary, so that the area unit Is $\mathrm{km}^{2}$ in all cases. Logarıthms are to the base 10 . Predicted richness values In parentheses are either extrapolated beyound the area range of the studied lakes, or the area range was unknown.

\begin{tabular}{|c|c|c|c|c|c|c|c|}
\hline \multirow[b]{2}{*}{ Regression equation } & \multirow[b]{2}{*}{ Area range } & \multirow{2}{*}{$\begin{array}{l}\text { No. of } \\
\text { lakes }\end{array}$} & \multirow[b]{2}{*}{$R^{2}$} & \multicolumn{3}{|c|}{ Predicted richness for $x \mathrm{~km}^{2}$} & \multirow[b]{2}{*}{ Source } \\
\hline & & & & 0.1 & 1 & 10 & \\
\hline$S=10.42 * A^{0143}$ & $0.8 \ldots 436000$ & 70 & 0.298 & (7.5) & 10.4 & 14.5 & Barbour \& Brown $(1974)^{\mathrm{a}}$ \\
\hline$S=3.86 * A^{039}$ & $-0.04 \ldots-40$ & 70 & 0.56 & 1.6 & 3.9 & 9.5 & Eadıe \& Keast (1984) \\
\hline $\mathrm{S}=7.52 * \mathrm{~A}^{0209}$ & $-0.001 \ldots>10000$ & 82 & 0.796 & 4.6 & 7.5 & 12.2 & Eadie et al. $(1986)^{b}$ \\
\hline$S=6.46 * A^{02}$ & $0.009 \ldots . .31 .6$ & 40 & 0.94 & 4.1 & 6.5 & 10.2 & Matuszek \& Beggs $(1988)^{\mathrm{C}}$ \\
\hline$S=9.77 * A^{02}$ & $0.1 \ldots 15.85$ & 11 & 0.94 & 6.2 & 9.8 & 15.5 & Matuszek et al. $(1990)^{d}$ \\
\hline$S=9.68+5.63 \log A$ & $<0.1 \ldots 100$ & 51 & 0.656 & 4.0 & 9.7 & 15.3 & Harvey (1978) \\
\hline$S=12.72+5.29 \log A$ & $<0.1 \ldots-10$ & 57 & 0.23 & 7.4 & 12.7 & 18.0 & Harvey (1981) \\
\hline$S=15.61+8.68 \log A$ & $0.05 \ldots 15.66$ & 100 & 0.496 & 6.9 & 15.6 & 24.3 & Rahel $(1986)^{e}$ \\
\hline$S=10.9 \cdot 5.8 \log A$ & $0.06 \ldots 1.78$ & 34 & 0.34 & 5.1 & 10.9 & $(16.7)$ & Somers \& Harvey (1984) \\
\hline$S=9.76 * A^{0346}$ & $0.02 \ldots 0.9$ & 18 & 0.50 & 4.4 & 9.8 & $(21.6)$ & Tonn \& Magnuson $(1982)^{\dagger}$ \\
\hline$S=8.65+4.33 \log A$ & $?$ & 54 & 0.63 & $(4.3)$ & $(8.6)$ & $(13.0)$ & Beamish et al. (1976), cited in Rahel (1986) \\
\hline$S=12.91+5.98 \log A$ & $?$ & 34 & 0.45 & $(6.9)$ & (12.9) & (18.9) & Keller (1984). cited in Rahel (1986) \\
\hline$S=10.99+3.07 \log A$ & $0.03-10.55$ & 16 & 0.87 & 7.9 & 11.0 & 14.1 & Present study \\
\hline
\end{tabular}

a Recalculated from the data provided in the paper. "Geometric mean regression (all other models are based on model I least-squares regression). Mean number of species in 40 subsets of lakes, grouped according to area (total number of lakes: 1928 . excluding lakes with pH<6.4). ${ }^{d}$ Mean number of species In 11 subsets of lakes, grouped accordıng to area (total number of lakes: 213 . excluding lakes ph<6.0). ${ }^{e}$ Low and high alkalınity lakes combined. ${ }^{\dagger}$ Recalculated from the data provided in the paper, summer assemblages only

are almost exlusively confined to running waters. 4 depend on lake tributary streams for reproduction and 20 are not present in northeastern Germany at all. Of the remaining 28 species, 19 have been found in our study lakes. Of the remaining 9 species, 5 are in danger of extinction or are severely threatened (Rote Liste Brandenburg 1992). The more species from a given species pool that are already present in a habitat, the lower is the probability that later arrivals belong to a new species. This effect is more pronounced when the regional species pool is small, and even more so when the species that are not present in the habitat are rare.

Even so. the slope of the species-area curve could be high if the smallest lakes contained only few species. i.e.. the intercept of the species-area curve was low. Species richness for the smallest lakes in this study, however. is high as compared with other studies (Table 3). There are only 4 of 12 studies in which predicted species richness for a 0.1 $\mathrm{km}^{2}$ lake is similar to, or higher than. the value (7.9 species) for the present set of lakes. For a 10 $\mathrm{km}^{2}$ lake. however, 8 of 12 studies predict higher richness than the present model (14.1 species). High species richness in the smallest lakes in this study is probably due to a set of factors: winters are not severe, so that the lakes sometimes do not freeze at all or they freeze only for some weeks. and winterkills do not occur in most lakes; reed belt and submersed vegetation provide ample spawning. feeding and hiding habitats: food resources are varied, although benthic food can be partly inaccessible due to hypolimnic anoxia during summer stagnation: and fish are not stressed by low $\mathrm{pH}$ values $(\mathrm{pH}$ is around 8$)$. Thus, habitat and food diversity and lack of stress from abiotic conditions in even the smallest lakes, together with the small regional pool of 28 species. are probably the main reasons for a low slope value combined with a high intercept value of the species-area relationship in the present data set.

The importance of habitat diversity for species richness is evidenced by the correlation between richness and shoreline development. Eadie \& Keast (1984) reported a similar observation for a combined set of northern and southern Ontario lakes. In the present study, however, the influence of shoreline development, and thus habitat complexity, is masked by the strong influence of area on species richness, because shoreline development is correlated with area. The narrow range of shoreline development $(1.2-3.5)$ does not allow the unequivocal separation of the influences of both factors on species richness.

Total dissolved solids are an indicator of the productivity level of a lake (Ryder et al. 1974). A high correlation between species richness and TDS was found for 15 lakes in this study. This in an indication that more productive lakes, where more food is available and resources can be finer subdivided. support more species (MacArthur 1972). A similar observation is reported by Tonn \& Magnuson (1982) for centrarchid-Esox assemblages in northern Wisconsin lakes. where conductivity was significantly related to fish species richness. No direct measures of food abundance or diversity are available for the present set of lakes, so the prediction that more productive lakes support more fish 
species cannot be tested rigorously at the moment. Additionally, the influence of TDS content (range: 194-438. $n=15$ ) is masked by the overwhelming influence of lake area in a multiple linear regression model.

It is often claimed in public discussion, and even some scientists favor the view. that fish communilies in lakes of northeastern Germany were severely affected by human impact during the last decades. For 14 lakes. 2 earlier species inventories are available for comparison. Both studies were carried out before these lakes were anthropogenically affected, mainly by nutrient input from domestic sewage. animal farming, intensive agriculture and intensive fish production. The main disadvantagc with these studies is that the occurrence of fish species was nol assessed by adequate sampling but recorded as personal communications from professional fishermen and residents. Therefore. the true species numbers might have been underestimated in these studies. To alleviate this potential bias, all fish species reported in either of these two studies were combined and compared with the present species list (Table 4). In 1992-1993, these 14 lakes had. on average. one species less than during the first half of this century. Since it has been estimated from a simple asymptotic modcl that contemporary species richness may be underestimated by roughly one species, this difference is negligible.

It is interesting that almost all lakes lost and gained fish species during the last decades, although average species richness remained unchanged. This might be considered further evidence for the strong correlation between species richness and lake area. There is. however, no relationship between the total number of lost and gained species per lake (i.e., species turnover rates) and the severity of human impact. The lakes that are most strongly polluted nowadays (Düstersee. Klarer See. Woiletzsee. Grimnitzsee and Großer Plunzsee) did not lose or gain more species (average turnover rate: 4.6) than the other lakes (average turnover rate: 5.1). Similarly. the lakes that were fished intensively with trap and seine nets are characterized by an average species turnover rate of 5 . which is not significantly different from the value of 4.8 for the lakes that were only fished with hook and line. An outstanding species loss occurred in Kleiner Plunzsee. a shallow. polytrophic lake. where nowadays in summer the living space for fish is compressed to $1.5-2 \mathrm{~m}$ and where winterkills are frequent.

Another argument is that specialist species are easier lost from a local species pool and replaced by generalist species. This argument is supported by the present data. Four bottom-living species (Lota lota. Silurus glanis, Cobitis taenia and Mis- 
gurnus fossilis) disappeared from 1-6 lakes but did not appear anew in any of the 16 lakes. This pattern is interpreted as a direct result of eutrophication-mediated habitat degradation. to which these species might be particularly susceptible. Apart from changes of species number or species composition, human impact may alter the relative abundance of particular species in a lake. Fish communities in most of the study lakes are nowadays dominated by roach. perch and bream. This is often attributed to anthropogenic impact. but precise data are lacking to support this contention.

In summary, neither changes in species richness or species turnover rates provide conclusive evidence that the fish communities in the study lakes were negatively affected by human influences during the last decades. On the species level. however. these influences are apparent: accelerated eutrophication was likely the ultimate cause for the disappearance of 4 bottom-living species, and it might have changed relative species abundances as well.

Appendix. Common and scientific names of fish species mentıoned in this study

\begin{tabular}{|c|c|c|}
\hline Scientific name & English & German \\
\hline Anguilla anguilla (L.) & eel & Aal \\
\hline $\begin{array}{l}\text { Oncorhynchus mykiss } \\
\text { (Walbaum) }\end{array}$ & raınbow trout & Regenbogentorelle \\
\hline Coregonus albula (L.) & vendace & Kleıne Maräne \\
\hline Coregonus lavaretus (L.) & whitefish & Große Maràne \\
\hline Esox lucius $\mathrm{L}$. & northern pike & Hecht \\
\hline Cyprinus carpio L. & common carp & Karpfen \\
\hline Abramis brama (L.) & common bream & Blei. Brachsen \\
\hline Alburnus alburnus (L.) & bleak & Ukelei \\
\hline $\begin{array}{l}\text { Aristichthys nobilis } \\
\text { Richardson }\end{array}$ & bighead carp & Marmorkarpfen \\
\hline Blicca bjoerkna (L.) & white bream & Güster. Blicke \\
\hline Carassius carassius (L.) & crucian carp & Karausche \\
\hline Gobio gobio (L.) & gudgeon & Gründling \\
\hline $\begin{array}{l}\text { Leucaspius delineatus } \\
\text { (Heckel) }\end{array}$ & $?$ & Moderleschen \\
\hline $\begin{array}{l}\text { Rhodeus sericeus amarus } \\
\text { (Bloch) }\end{array}$ & bittering & Bitterling \\
\hline Rutilus rutilus (L.) & roach & Plötze, Rotauge \\
\hline $\begin{array}{l}\text { Scardinius } \\
\quad \text { erythrophthalmus (L.) }\end{array}$ & rudd & Rotfeder \\
\hline Tinca tinca (L.) & tench & Schleie \\
\hline Cobitis taenia L. & spined loach & Stennbeißer \\
\hline Misgurnus fossilis (L.) & $?$ & Schlammpeitzger \\
\hline Silurus glanis L. & European catfish, wels & Wels \\
\hline Gasterosteus aculeatus $\mathrm{L}$. & three-spined stickleback & Dreistachliger Stichling \\
\hline Perca fluviatil/s $\mathrm{L}$. & Eurasian perch & Barsch, Flußbarsch \\
\hline $\begin{array}{l}\text { Gymnocephalus cernua } \\
\text { (L.) }\end{array}$ & ruffe & Kaulbarsch \\
\hline $\begin{array}{l}\text { Stizostedion lucioperca } \\
\text { (L.) }\end{array}$ & zander & Zander \\
\hline Lota lota (L.) & burbot & Quappe. Trusche \\
\hline
\end{tabular}

\section{Resumen}

1. La abundancia de especics de peees se ha estudiado en 16 lagos del noreste de Alemania (reservá de la biosfera "Schorfheide") mediante pesca clćctrica y redes de enmalle. La superfície de los lagos oscila entre 0.03 y $10.55 \mathrm{~km}^{2}$. donde habitan de 5 a 14 especies.

2. La abundancia dc especies está significativamente correlacionada con la superfície de los lagos. el desarrollo de la orilla y la cantidad de sólidos disueltos. Dichas correlaciones respaldan la hipótesis de que en los grandes lagos habitan más especies de un mismo gr upo taxonómico debido a una mayor diversidad de hábitats

3. La pendiente de la relación número de especies-superfície de los lagos es menor que la obtenida en estudios similares. siendo mayor el punto de corte. Esto se debe a la alta diversidad de hábitals y de las fuentes de alimentación. a la ausencia de alteraciones de orden abiótico y al bajo numero de especies presentes en la región.

4. Si se compara con la información existente. la abundancia media de las especies no ha cambiado durante las últimas déeadas.

5. La lasa de renovación de las especies parece que no está relacionada con el grado de eutrofización antropogénica ni con la intensidad de la explotación pesquera. Sin embargo. a nivel de especie. cuatro especies bentónieas han desaparecido en 6 lagos por calusil de la eutrofización.

\section{Acknowledgements}

I am indebted to Karl Anwand for advice and active participation in this study. to Christian Helms for invaluable assistance in all fishing operations and lield work in general. to Karin Kleibs and Monika Valentin for help in sample processing and to J. Gelbrecht and $\mathrm{H}$. Behrendt, who performed the analyses of TDS. total P and chlorophyll a. The manuscript benefited greatly from the comments of two anonymous referees.

\section{References}

Angermeier, P.L. \& Schlosser. I.J. 1989. Species-area relationships for stream fishes. Ecology 70: 14501462.

Barbour. C.D. \& Brown. J.H. 1974. Fish species diversity in Lakes. The American Naturalist 108: 473-489.

Brönmark. C. 1985. Freshwater snail diversity: effects of pond area. habitat heterogeneity, and isolation. Oecologia 67: 127131

Browne. R.A. 1981. Lakes as islands: the biogeographic distribution. turnover rates, and species composition in the lakes of central New York. Journal of Biogeography 8: 75-83.

Connor, E.F. \& McCoy. E.D. 1979. The statistics and biology of the species-area relationship. The American Naturalist 113:791-833

Dodson. S. 1991. Species richness of crustacean zooplankton in European lakes of different sices. Verhandlungen der internationalen Vereinigung für Limnologie 24: $1223 \quad 1229$

Eadie. J.M.A. \& Keast. A. 1984. Resource heterogeneily and fish species diversity in lakes. Canadian Journal of Zoology 62: 16891695

Eadie. J.M.A.. Hurly, T.A.. Montgomerie. R.S. \& Teather, K.L. 1986. Lakes and rivers as islands: species-area relationships in the fish faunas of Ontario. Environmental Biology of Fishes 15:81-89.

Ecksten, K. 1908. Die Fischerei-Verhälınisse der Provinz Brandenburg zu Anfang des 20. Jahrhunderts. II. Teil. Berlin: Verlag des Fischerei-Vereins für die Provinz Brandenburg. $275 \mathrm{pp}$.

Fryer. G. 1985. Crustacean diversity in relation to the size of 
water bodies: some facts and problems. Freshwater Biology 15: 347-361.

Harvey, H.H. 1978. Fish communities of the Manitoulin Island lakes. Verhandlungen der internationalen Vereinigung für Limnologie 20: 2031-2038.

Harvey, H.H. 1981: Fish communities of the lakes of the Bruce Peninsula. Verhandlungen der internationalen Vereinigung für Limnologie 21: 1222-1230.

Ladiges. W. \& Vogt. D. 1979. Die Süsswasserfische Europas bis zum Ural und Kaspischen Meer. 2nd edn. Hamburg: Paul Parey. $299 \mathrm{pp}$.

MacArthur, R.H. 1972. Geographical ecology. Patterns in the distribution of species. New York: Harper \& Row. xviii +267 pp.

MacArthur. R.H. \& Wilson, E.O. 1967. The theory of island biogeography. Princeton. N.J.: Princeton University Press. $\mathrm{xi}+203 \mathrm{pp}$

Magnuson. J.J. 1976. Managing with exotics - a game of chance. Transactions of the American Fisheries Society 105: $1-9$

Macuszek, J.E. \& Beggs. G.L. 1988. Fish species richness in relation to lake area, $\mathrm{pH}$, and other abiotic factors in Ontario lakes. Canadian Journal of Fisheries and Aquatic Sciences 45: 1931-1941.

Matuszek. J.E. Goodier, J. \& Wales, D.L. 1990. The occurrence of cyprinidae and other small fish species in relation to $\mathrm{pH}$ in Ontario lakes. Transactions of the American Fisheries Society 119: 850-861.

Preston. F.W. 1960. Time and space and the variation of species. Ecology 41: 6i 1-627.

Rahel, F.J. 1986. Biogeographic influences on fish species composition of Northern Wisconsin lakes with applications for lake acidification studies. Canadian Journal of Fisheries and Aquatic Sciences 43: 124-134.

Rote Liste Gefährdete Tiere in Land Blandenburg. 1942. Postdam: Ministerium für Umwelt, Naturschutz und Rauinordnung. $288 \mathrm{pp}$.

Ryder.R.A.. Kerr. S.R.. Loftus. K.H. \& Regier. H.A. 1974. The morphoedaphic index, a fish yield estimator review and evaluation. Journal of the Fisheries Research Board of Canada $31 \cdot 663-688$

Somers. K.M. \& Harvey. H.H. 1984. Alteration of fish communities in lakes scressed by acid deposition and heavy metals near Wawa, Ontario. Canadian Journal of Fisheries and Aquatic Sciences $41 \quad 20-29$.

Tonn. W.M. \& Magnuson. J.J. 1982: Patterns in the species composition and richness of fish assamblages in northern Wisconsin lakes. Ecology 63: $1149-1166$.

Williams, C.B. 1964. Patterns in the balance of nature. London: Academic Press. 324 pp. 